\title{
Ecocracy dalam Pengembangan Destinasi Pariwisata
}

\author{
Erma Ariyani ${ }^{1}$, Priskadini April Insani, Trysilvana Azwari \\ Universitas Lambung Mangkurat
}

\begin{abstract}
In a democratic country, it certainly puts forward the principles of democracy. In this time, the tourism industry in Indonesia has great potential in the Indonesian economy. Along with its development, government policies in developing tourism destinations that have the potential to increase foreign exchange are expected to be sustainable development. Especially in terms of the environment where the concept of ecocracy itself is a form of recognition of nature. In this article use literature studies. The results obtained are addressing all government policies relating to the tourism sector without disrupting existing ecosystems. So that there needs to be steps that must be carried out by the government and there needs to be steps that must be taken for businesses in the tourism industry. Without harming people's rights around the tourism destination that will be developed.
\end{abstract}

Keywords : Democratic, Tourism, Ecocracy, Environment

\begin{abstract}
Abstrak
Dalam sebuah negara yang demokrasi, pastinya mengedepankan prinsip-prinsip demokrasi. Saat ini industri pariwisata di Indonesia memiliki potensi besar dalam perekonomian bangsa Indonesia. Seiring dengan perkembangannya, kebijakan pemerintah dalam mengembangkan destinasi pariwisata yang berpotensi bagi peningkatan devisa negara diharapkan pengembangannya juga berkelanjutan. Terutama dari segi lingkungan dimana konsep ecocracy itu sendiri merupakan bentuk pengakuan terhadap alam. Dalam artikel ini menggunakan studi literatur. Hasil yang didapatkan ialah menyikapi segala kebijakan pemerintah yang berkaitan dengan sektor pariwisata tanpa mengganggu ekosistem yang ada. Sehingga perlu adanya langkah-langkah yang wajib dilakukan oleh pemerintah serta perlu adanya langkah yang harus dilakukan bagi pelaku usaha di industri pariwisata. Tanpa merugikan hak-hak masyarakat yang ada di sekitar destinasi pariwisata yang akan dikembangkan.
\end{abstract}

Kata Kunci : Demokrasi, Pariwisata, Ecocracy, Lingkungan

${ }^{1}$ Erma.ariyani@ulm.ac.id 


\section{Pendahuluan}

Industri pariwisata di Indonesia begitu menjajikan dan sangat berpotensi besar dalam peningkatan kesejahteraan bagi masyarakat serta mendatangkan devisa bagi negara. Berdasarkan data dari Kementerian Pariwisata dalam Rencana Strategis Pengembangan Destinasi dan Industri Pariwisata tahun 2015-2019 menyatakan bahwa sektor pariwisata masuk dalam peringkat ke empat nasional setelah gas, batu bara, dan kelapa sawit serta mampu menyerap tenaga kerja dalam jumlah yang fantastis. Tidak hanya itu saja sektor pariwisata juga mampu mendatangkan seseorang dari belahan dunia manapun untuk mengunjungi Indonesia. Tak hanya wisatawan dari luar negeri bahkan wisatawan dalam negeripun juga suka berwisata di era masa kini. Sehingga devisa negara mengalami banyaak peningkatan. Kelebihan inilah yang menjadi sangat menarik untuk dikaji lebih mendalam dalam konteks akademis.

Sejalan dengan perkembangan industri pariwisata di Indonesia yang begitu pesat perlu ada langkah-langkah konkrit dalam mewujudkannya. Salah satunya ialah dengan pengembangan destinasi pariwisata yang ada di Indonesia. Kementerian Pariwisata melihat fenomena tersebut dalam jangka panjang melalui Direktorat Jenderal Pengembangan Destinasi Pariwisata (Ditjen PDP) dengan mengembangkan program utama Direktorat Jenderal). Hal tersebut didukung dengan visi: "Mengembangkan Destinasi dan Industri PariwisataBerkelas Dunia, Berdaya Saing, dan Berkelanjutan serta Mampu Mendorong Pembangunan Daerah", yang kemudian diklasifikasikan menjadi 3 misi utama, yaitu:

1. Peningkatan kontribusi ekonomi kepariwisataan melalui pengembangan destinasi;

2. Peningkatan daya saing kepariwisataan Indonesia melalui pengembangan destinasi; dan

3. Menciptakan tata pemerintahan Ditjen PDP yang responsif, transparan dan akuntabel. (Ditjen PDP)

Data yang diperoleh dari Ditjen PDP dalam pengembangan destinasi pariwisata yang telah tercapai di tahun 2010-2014 sesuai dengan masterplan diantaranya adalah: adanya Kawasan Ekonomi Khusus diantara ada KEK 
Mandalika di NTB, KEK Tanjung Lesung di Banten; sehubungan dengan PP no. 50 tahun 2011 tentang Ripparnas telah disusun Rencana Detail Kawasan Strategis Pariwisata Nasional (KSPN) diantaranya ada KSPN Toba, KSPN Komodo, KSPN Sanur Nusa Dua Kuta, KSPN Bromo Tengger Semeru, KSPN Toraja, KSPN Kepulauan Seribu; penerapan program tata kelola destinasi pariwisata; serta penyusunan profil investasi dan promosi investasi sektor pariwisata.

Semakin berkembangnya industri pariwisata ini maka juga harus dipertimbangkan dampak-dampak terhadap lingkungan. Oleh sebab itu dalam pengembangan destinasi pariwisata diharapkan dapat mewujudkan sinergi yang baik terhadap lingkungan, melalui pembangunan yang berkelanjutan (sustainable development). Dalam artikel ini akan mengkritisi bagaimana suatu demokrasi dapat menanggapi sebuah krisis yang dihadapai oleh lingkungan melalui sektor pariwisata?

\section{Metode Penelitian}

Penulisan artikel ini menggunakan studi literatur dengan tujuan untuk menggali informasi yang mendalam melalui identifikasi permasalah dari berbagai sumber yang berkaitan melalui pengumpulan bebagai jurnal maupun buku-buku yang relevan. Dengan digunakannya berbagai macam literatur ini agar dapat mendesain solusi yang dapat diimplementasikan dalam pembahasan ecocracy di sektor pariwisata.

\section{Hasil dan Pembahasan}

Apabila berbicara tentang ecocracy maka harus dipahami terlebih dahulu makna dari ecocracy tersebut. Kata tersebut berasal dari kata yaitu ekologi dan demokrasi. Dimana makna ekologi adalah suatu integritas ekosistem yang saling mendukung dalam siklus kehidupan melalui proses-proses biologi (Triana, 7:2014). Sedangkan demokrasi berasal dari dua suku kata yaitu demos dan kratos. Demos yang berarti warga atau warga negara, sedangkan kratos berarti kekuasaan untuk mengatur atau memberlakukan sebuah aturan. Sehingga pengertian dari demokrasi 
bermakna pemerintahan yang berdasarkan pada kedaulatan rakyat dalam mewujudkan masa depan sebuah bangsa (Mathews, 26:71)

Sehingga konsep ecocracy itu sendiri merupakan bentuk pengakuan terhadap alam, oleh sebab itu perlu adanya sebuah pemahaman tentang keterbatasan dari sebuah lingkungan yang harus diperhatikan dengan tidak merusak tatanan sistem suatu ekologi dan tidak bertindak secara eksploitatif demi kepentingan pribadi serta tidak mengesampingkan kondisi alam. Oleh sebab itu perlu adanya pengaturan yang concern terhadap lingkungan.

Lingkungan hidup yang sehat dan berkualitas telah dijamin dalam peraturan pemerintah. Di Indonesia, Undang-Undang No. 32 tahun 2009 tentang Perlindungan dan Pengelolaan Lingkungan Hidup, hal ini sesuai dengan penjelasan pada Pasal 3 bahwa perlindungan dan pengelolaan lingkungan hidup itu bertujuan untuk: (a) melindungi wilayah Negara Kesatuan Republik Indonesia dari pencemaran dan/atau kerusakan lingkungan hidup; (b) menjamin keselamatan, kesehatan, dan kehidupan manusia; (c) menjamin kelangsungan kehidupan makhluk hidup dan kelestarian ekosistem; (d) menjaga kelestarian fungsi lingkungan hidup; (e) mencapai keserasian, keselarasan, dan keseimbangan lingkungan hidup; (f) menjamin terpenuhinya keadilan generasi masa kini dan generasi masa depan; (g) menjamin pemenuhan dan perlindungan hak ataslingkungan hidup sebagai bagian dari hak asasi manusia; (h) mengendalikan pemanfaatan sumber daya alam secara bijaksana; (i) mewujudkan pembangunan berkelanjutan; dan (j) mengantisipasi isu lingkungan global.

Secara sederhana ecocracy ini berpedoman pada ekologi berdasarkan demokrasi yang bertujuan untuk menciptakan sistem yang berkelanjutan atau dalam hal ini disebut sustainable development. Hal ini agar tatanan kehidupan yang ada di alam dapat berguna dalam jangka panjang. Perlu menjadi sebuah perhatian bagi private sector maupun public sector yang akan melakukan pengembangan dalam destinasi pariwisata ini agar keberadaannya tidak merugikan lingkungan maupun masyarakatnya. 
Menurut ahli teori ekonomi lingkungan (Daly,1990 dalam Castro, 2004) membagi 2 kelompok dalam memaknai sustainable development ini yaitu: (1) strong sustainability, yang menyatakan bahwa sumber daya alam wajib dilindungi sedangkan (2) weak sustainability, bahwa sumber daya dibuat oleh manusia dan disediakan oleh alam. Berdasarkan pendapat yang dikemukakan oleh Zusmelia (2007:8) mengatakan bahwa

"Gagasan sustainable development dalam artian yang sesungguhnya masih jauh dari kenyataan. Selagi adanya upaya untuk mengaitkan negara pinggiran ke negara maju oleh pasar, dan memperkenalkan pasar sebagai suatu solusi untuk kemiskinan dan keberlanjutan lingkungan, selama itulah pembangunan berkelanjutan semakin jauh dari pemikiran baru kaum ekologi lingkungan".

Sebuah kritik dari pemikiran Faucault dalam aliran post-strukturalis mendukung negara berkembang sebagai objek pembangunan yang kemudian akan melahirkan kaum environmentalist yang concern pada indigenous knowledge. Dalam hal ini pemikiran Faulcault termasuk dalam strong development. Sedangkan kaum Marxisme (neo-Marxist) telah mendefinisikan bahwa pembangunan berkelanjutan adalah pertumbuhan ekonomi dalam bentuk kapitalis. Dalam hal ini, Marxisme tergolong weak sustainability. (Castro, 2004 dalam Zusmelia (2007:8).

Konstitusi dalam tataran globalyang mengatur tentang perlindungan terhadap lingkungan, salah satunya melalui Charter of Fundamental Rights of the European Union dalam Pasal 37, telah disebutkan sebagai berikut:

"A high level of environmental protection and the improvement of the quality of the environment must be integrated into the policies of the Union and ensured in accordance with the principle of sustainable development".

Fenomena yang terjadi di Indonesia seperti kasus yang ada dalam artikel ini telah dimuat dalam berita online kompas bahwa pariwisata di Indonesia mengusung konsep ecotourism dimana hal tersebut dapat menjanjikan peningkatan perekonomian masyarakat. Berdasarkan data yang diperoleh dari Ditjen PDP memang kawasan wisata Mandalika masuk dalam program masterplan dari Kementerian Pariwisata dalam pengembangan destinasi pariwisata dimana kawasan wisata Mandalika termasuk dalam Kawasan Ekonomi Khusus (KEK). Hal tersebut 
didukung oleh pemerintah baik dari segi infrastruktur dasar dengan dana sekitar 1,8 triliun.

Dapat dideskripsikan bahwa kasus yang terjadi di Labuan Bajo yang bersumber dari berita online www.kpa.or.id bahwa pemerintah optimis untuk melakukan pengembangan destinasi pariwisata melalui Konservasi Labuan BajoKomodo. Fenomena alam yang menarik diharapkan dapat mendatangkan wisatawan baik domestik maupun mancanegara untuk datang ke destinasi tersebut. Hal tersebut berdampak positif bagi pertumbuhan PAD di salah satu Kabupaten di Nusa Tenggara serta dapat mengangkat derajad hidup dari segi perekonomian warga masyarakatnya. Akan tetapi dampak negatifpun juga akan ditimbulkan dari pengembangan destinasi yang ada di wilayah Labuan Bajo-Komodo, bahwa berkurangnya hak masyarakat dalam pengelolaan atas tanah dari jual beli pulau, berkurangnya akses melaut bagi nelayan karena penetapan batas konservasi Komodo sehingga nelayan lebih jauh berlayar dan membutuhkan biaya operasional lebih besar, keterbatasan pengelolaan hutan bagi masyarakat lokal sebagai sumber kehidupan dalam penggunaan kayu dan air bersih dan akses pendidikan yang sulit bagi sekolah di wilayah konservasi komodo sehingga bukan berinduk di wilayah Dinas Pendidikan NTT akan tetapi di Dinas Pendidikan NTB. Sehingga dari beberapa polemik ini banyak menimbulkan aksi protes bagi masyarakat lokal. Terkadang juga merusak habitat laut serta membuang sampah sembarangan. Bagaimana habitat komodo tidak terganggu bila dalam jangka panjang tidak diperhatikan ekosistemnya. Padahal komodo adalah salah satu binatang yang langka dan hanya dimiliki oleh Indonesia. Sehingga kasus dari Konservasi Labuan BajoKomodo ini perlu diperhatiakan agar dapat memberikan jalan keluar yang baik bagi masyarakat lokal agar tidak dirugikan akibat adanya konservasi ini serta berdampak baik bagi habitat komodo. Perlu diketahui pula, bila Kawasan pariwisata dan konservasi Labuan Bajo-Komodo merupakan salah satu Kawasan Strategis Pariwisata Nasional (KSPN) yang telah ditetapkan oleh pemerintah.

Oleh Sebab itu perlu ada langkah-langkah yang startegis agar pembangunan destinasi pariwisata dapat berjalan sustainable. (1) Demokrasi dalam krisis lingkungan, pemerintah Indonesia dalam hal ini sangat memperhatikan terkait 
dengan isu global terhadap lingkungan. Beberapa langkah yang memang diperhatikan agar keberlangsungan lingkungan dapat bekelanjutan. Masyarakat menjadi waspada, yang dimaksud terkhusus pada individu terlebih dahulu mulai mengubah mindset dalam skala kecil seperti mengubah pola konsumsi. Pola konsumsi ini diharapkan agar ramah lingkungan. Konsumsi yang dimaksud lebih ke sektor pariwisata yang berpekspektif terhadap lingkungan. Misalnya, para wisatawan berhak menggunakan destinasi pariwisata secara leluasa akan tetapi tidak boleh merusak ekosistem lingkungannya. Seperti membuang sampah pada tempatnya serta adanya pemilahan sampah baik plastik, kertas, maupun dedaunan. Serta hasil keluaran tersebut juga berupa limbah baik padat maupun cair. Antisipasi pemerintah, selain dari pola pikir dari masyarakat terlebih dahulu, pemerintah juga menegakkan peraturan-peraturan hukum bagi pelaku di dunia pariwisata serta tidak melalaikan keberlanjutan lingkungan. (2) Kepentingan pribadi terhadap perlindungan alam, Indonesia adalah sebuah negara yang demokratis yang telah menjamin masyarakatnya dalam perlindungan hukum. Apabila setiap investor yang ingin berinvestasi di Indonesiapun juga tidak lepas dari peraturan pemerintah yang mendasarinya, mulai dari adanya IMB, AMDAL, uji air dan limbah, adanya dokumen UKP-UPL yang harus dipenuhi terlebih dahulu sehingga keberlangsungannyapun dapat dipertanggungjawabkan. Agar tidak hanya pembangunan destinasi pariwisata saja tetapi juga melakukan konservasi alam. (3) Skenario politik dalam reformasi lingkungan, fakta di Indonesia telah menyebutkan adanya perencanaan 10 Kawasan Ekonomi Khusus yang ada di Indonesia untuk mendukung pengembangan destinasi pariwisata (Heilbroner, 1974; Ophuls, 1977 dalam Mathew, 2005: 57). Secara teori, Filosofi politik telah menunjukkan bahwa pembagian antara publik maupun privat adalah salah satu sarana utama yang membatasi keterbatasan demokrasi. Hal ini juga penting bagi sarana demokrasi yang terbatas pada area sempit kehidupan politik publik sehingga mudah dikendalikan oleh para elit yang mendapat manfaat dari kerusakan lingkungan. Adanya kontrol demokratis dari para pemangku kebijakan dan mencegah realisasinya dimana politik sebagai subjek sosial (Okin, 1991; Pateman, 1989 dalam Mathew, 2005: 149). 
Selanjutnya peraturan di Indonesia yang berkaitan dengan lingkungan hidup diantaranya Pasal 28H ayat (1) UUD 1945 yaitu: "Setiap orang berhak hidup sejahtera lahir dan batin, bertempat tinggal, dan mendapatkan lingkungan hidup yang baik dan sehat serta berhak memperoleh pelayanan kesehatan”. Kemudian juga Pasal 33 ayat (3) UUD 1945 yaitu: "Bumi, air, dan kekayaan alam yang terkandung didalamnya dikuasai oleh Negara dan dipergunakan untuk sebesarbesarnya kemakmuran rakyat”. Serta Pasal 33 ayat (4) UUD 1945 yaitu: "Perekonomian nasional diselenggarakan berdasar atas demokrasi ekonomi dengan prinsip kebersamaan, efisiensi berkeadilan, berkelanjutan, berwawasan lingkungan, kemandirian, serta dengan menjaga keseimbangan kemajuan dan kesatuan ekonomi nasional". Bahwa dipastikan setiap masyarakat mendapatkan lingkungan yang layak tanpa adanya pencemaran yang berasal dari lingkungan mulai dari limbah, sampah, polusi udara dsb. Serta adanya pengharapan dari perekonomian nasional melalui sektor pariwisata dapat memajukan perekonomian nasional dengan tetap memperhatikan lingkungan.

Agar destinasi pariwisata dapat berkelanjutan dengan mengedepankan prinsip ecocracy maka hal yang harus diperhatikan antara lain:

1) pro ekonomi kesejahteraan adalah diharapkan dapat meningkatkan perekonomian bagi seluruh masyarakat,

2) pro lingkungan berkelanjutan adalah dapat menjaga keseimbangan lingkungan hidup,

3) pro keadilan sosial adalah masyarakat dapat mendapatkan keadilan dalam mengakses sumber daya alam yang tersedia,

4) pro lingkungan hidup yaitu memperhatikan kondisi lingkungan agar ekosistemnya tidak terganggu akibat pencemaran lingkungan, Sutisna (2006:9). 
Banyak tantangan yang terkait dengan pengembangan destinasi pariwisata mulai dari polemik bagi masyarakat yang akan timbul kemudian terhadap dampak lingkungan di masa depan. Adapun langkah-langkah yang harus diperhatikan bagi pemerintah (Weaver, 2006:120) antara lain:

\begin{tabular}{|c|c|c|}
\hline No & Langkah-Langkah & Keterangan \\
\hline 1. & Adanya visi dan tujuan & $\begin{array}{l}\text { Penilaian kemajuan menuju pembangunan } \\
\text { berkelanjutan harus dipandu oleh visi yang } \\
\text { jelas tentang pembangunan berkelanjutan } \\
\text { dan tujuan yang menentukan visi tersebut. }\end{array}$ \\
\hline 2. & Perspektif holistik & $\begin{array}{l}\text { - mempertimbangkan kesejahteraan sub- } \\
\text { sistem sosial, ekologi dan ekonomi, dan } \\
\text { interaksi antar bagian } \\
\text { - mempertimbangkan konsekuensi positif } \\
\text { dan negatif dari aktivitas manusia, dengan } \\
\text { cara yang mencerminkan biaya dan manfaat } \\
\text { untuk manusia dan ekologi }\end{array}$ \\
\hline 3. & $\begin{array}{l}\text { Memperhatikan elemen- } \\
\text { elemen penting }\end{array}$ & $\begin{array}{l}\text { - mempertimbangkan kesetaraan dan } \\
\text { disparitas dalam populasi saat ini antara } \\
\text { generasi sekarang dan mendatang, } \\
\text { memperhatikan penggunaan sumber daya, } \\
\text { konsumsi berlebihan dan kemiskinan, serta } \\
\text { hak asasi manusia } \\
\text { - mempertimbangkan kondisi ekologi yang } \\
\text { menjadi tempat bergantungnya kehidupan } \\
\text { - mempertimbangkan perkembangan } \\
\text { ekonomi dan kegiatan non-pasar lainnya } \\
\text { yang berkontribusi terhadap kesejahteraan } \\
\text { manusia/ sosial }\end{array}$ \\
\hline 4. & $\begin{array}{l}\text { Ruang lingkup yang } \\
\text { memadai }\end{array}$ & $\begin{array}{l}\text { - mengadopsi horison waktu yang cukup } \\
\text { panjang untuk menangkap skala waktu } \\
\text { manusia dan ekosistem sehingga } \\
\text { menanggapi arus kebutuhan dalam } \\
\text { pengambilan keputusan jangka pendek serta } \\
\text { generasi masa depan } \\
\text { - menentukan ruang belajar yang cukup } \\
\text { luas untuk tidak hanya mencakup dampak } \\
\text { lokal tetapi juga jarak jauh pada masyarakat } \\
\text { dan ekosistem } \\
\text { - memperhatikan kondisi historis dan saat } \\
\text { ini untuk mengantisipasi kondisi di masa } \\
\text { depan }\end{array}$ \\
\hline
\end{tabular}




\begin{tabular}{|c|c|c|}
\hline 5. & Fokus praktis & $\begin{array}{l}\text { - menghubungkan visi dan tujuan ke } \\
\text { indikator dan penilaian kriteria } \\
\text { - sejumlah masalah penting untuk analisis } \\
\text { - standardisasi pengukuran sedapat } \\
\text { mungkin untuk mengetahui target, nilai } \\
\text { referensi, rentang, ambang batas, atau arah } \\
\text { tren, yang sesuai }\end{array}$ \\
\hline 6. & Keterbukaan & $\begin{array}{l}\text { - membuat metode dan data yang } \\
\text { digunakan dapat diakses oleh semua orang }\end{array}$ \\
\hline 7. & Komunikasi yang efektif & $\begin{array}{l}\text { - dirancang untuk memenuhi kebutuhan } \\
\text { masyarakat } \\
\text { - bertujuan, dari awal, untuk kesederhanaan } \\
\text { dalam struktur dan penggunaan bahasa yang } \\
\text { jelas dan sederhana }\end{array}$ \\
\hline 8. & Partisipasi luas & $\begin{array}{l}\text { - mendapatkan perwakilan luas dari semua } \\
\text { golongan, termasuk pemuda, wanita dan } \\
\text { masyarakat adat untuk memastikan } \\
\text { pengakuan nilai-nilai yang beragam dan } \\
\text { berubah } \\
\text { - memastikan partisipasi pengambil } \\
\text { keputusan untuk ke kebijakan }\end{array}$ \\
\hline 9. & Penilaian berkelanjutan & $\begin{array}{l}\text { - bersifat berulang, adaptif, dan responsif } \\
\text { terhadap perubahan dan ketidakpastian } \\
\text { karena sistem bersifat kompleks dan } \\
\text { seringnya berubah } \\
\text { - menyesuaikan sasaran, kerangka kerja, } \\
\text { dan indikator saat wawasan baru diperoleh }\end{array}$ \\
\hline 10. & Kapasitas kelembagaan & $\begin{array}{l}\text { - menetapkan tanggung jawab secara jelas } \\
\text { dan memberikan dukungan berkelanjutan } \\
\text { dalam proses pengambilan keputusan } \\
\text { - menyediakan kapasitas kelembagaan } \\
\text { untuk pengumpulan data, pemeliharaan, dan } \\
\text { dokumentasi }\end{array}$ \\
\hline
\end{tabular}

Indonesia juga harus mematuhi aturan global tentang pengembangan destinasi pariwisata ini sehingga para investor maupun pelaku industri pariwisata juga mempunyai perhatian khusus terhadap lingkungan tidak hanya menghasilkan benefit dari segi finansial saja. Upaya-upaya yang dilakukan antara lain: 


\begin{tabular}{|c|c|c|}
\hline No & Upaya-Upaya & Keterangan \\
\hline 1. & $\begin{array}{l}\text { Melestarikan } \\
\text { lingkungan alam, } \\
\text { ekosistem dan } \\
\text { keanekaragaman } \\
\text { hayati }\end{array}$ & $\begin{array}{l}\text { - berkontribusi terhadap konservasi setiap } \\
\text { habitat flora dan fauna akibat dipengaruhinya } \\
\text { oleh kegiatan pariwisata } \\
\text { - mendorong otoritas yang relevan untuk } \\
\text { mengidentifikasi area yang layak untuk } \\
\text { konservasi dan untuk menentukan level } \\
\text { pengembangan pariwisata } \\
\text { - peningkatan dan tindakan korektif di sektor } \\
\text { pariwisata untuk melestarikan margasatwa dan } \\
\text { ekosistem alam. }\end{array}$ \\
\hline 2. & $\begin{array}{lr}\text { Menghormati } & \text { dan } \\
\text { mendukung tradisi, } & \text { dan } \\
\text { budaya, } & \text { komunitas setempat }\end{array}$ & $\begin{array}{l}\text { - memastikan bahwa sikap masyarakat, adat } \\
\text { istiadat setempat dan nilai-nilai budaya serta } \\
\text { peran perempuan dan anak-anak terkait } \\
\text { pariwisata } \\
\text { - memberikan peluang bagi masyarakat yang } \\
\text { lebih luas untuk mengambil bagian dalam } \\
\text { diskusi tentang masalah perencanaan pariwisata } \\
\text { di mana ini mempengaruhi industri pariwisata } \\
\text { dan masyarakat } \\
\text { - mendorong otoritas yang relevan untuk } \\
\text { mengidentifikasi warisan budaya yang layak } \\
\text { untuk konservasi dan untuk menentukan } \\
\text { pengembangan pariwisata } \\
\text { b berkontribusi terhadap identitas dan } \\
\text { kebanggaan masyarakat lokal melalui } \\
\text { penyediaan produk dan layanan pariwisata yang } \\
\text { berkualitas serta peka terhadap komunitas } \\
\text { tersebut }\end{array}$ \\
\hline 3. & $\begin{array}{l}\text { Mempertahankan } \\
\text { sistem manajemen } \\
\text { lingkungan }\end{array}$ & $\begin{array}{l}\text { - memastikan bahwa penilaian lingkungan } \\
\text { merupakan langkah integral dalam perencanaan } \\
\text { proyek pariwisata } \\
\text { - mendorong audit praktik lingkungan secara } \\
\text { teratur di seluruh industri pariwisata dan } \\
\text { mempromosikannya } \\
\text { - menetapkan kebijakan dan indikator } \\
\text { lingkungan dan/ atau pedoman rinci untuk } \\
\text { berbagai sektor pariwisata industri } \\
\text { - menggabungkan desain dan konstruksi } \\
\text { terhadap lingkungan di setiap bangunan pada } \\
\text { sektor pariwisata. }\end{array}$ \\
\hline 4. & $\begin{array}{l}\text { Menghemat dan } \\
\text { mengurangi energi, } \\
\text { limbah, dan polutan }\end{array}$ & $\begin{array}{l}\text { - menumbuhkan rasa yang bertanggung jawab } \\
\text { terhadap lingkungan untuk: } \\
\text { - Mengurangi polutan dan gas rumah kaca } \\
\text { - Melestarikan air dan melindungi kualitas air }\end{array}$ \\
\hline
\end{tabular}




\begin{tabular}{|c|c|c|}
\hline & & $\begin{array}{l}\text { - Mengelola limbah dan energi secara efisien } \\
\text { - Mengendalikan tingkat kebisingan dan } \\
\text { - Mempromosikan penggunaan bahan yang bisa } \\
\text { didaur ulang dan yang bisa terurai. }\end{array}$ \\
\hline 5. & $\begin{array}{lr}\text { Mendorong } & \text { komitmen } \\
\text { pariwisata } & \text { terhadap } \\
\text { lingkungan } & \text { dan } \\
\text { budaya } & \end{array}$ & $\begin{array}{l}\text { - mendorong mereka yang terlibat dalam } \\
\text { pariwisata untuk mematuhi kebijakan } \\
\text { perencanaan lokal, regional dan nasional dan } \\
\text { untukberpartisipasi dalam proses perencanaan } \\
\text { - membantu perkembangan yang berperan } \\
\text { dalam kegiatan pariwisata serta kesadaran akan } \\
\text { lingkungan dannilai-nilai budaya } \\
\text { - mendorong semua pihak yang memberikan } \\
\text { layanan kepada perusahaan pariwisata untuk } \\
\text { berpartisipasi melalui lingkungan dantindakan } \\
\text { yang bertanggung jawab secara sosial } \\
\text { - mendukung kesadaran lingkungan dan budaya } \\
\text { melalui pemasaran pariwisata. }\end{array}$ \\
\hline 6. & $\begin{array}{lr}\text { Mendidik } & \text { dan } \\
\text { memberi tahu orang } \\
\text { lain tentang } \\
\text { lingkungan } \\
\text { budaya setempat }\end{array}$ & $\begin{array}{l}\text { - mendukung penyertaan nilai-nilai lingkungan } \\
\text { dan budaya dalam pendidikan, pelatihan dan } \\
\text { perencanaan kepariwisataan } \\
\text { - meningkatkan apresiasi dan pemahaman oleh } \\
\text { wisatawan tentang lingkungan alam dan } \\
\text { kepekaan budaya melalui penyediaan informasi } \\
\text { yang akurat dan interpretasi yang tepat } \\
\text { - mendorong dan mendukung penelitian } \\
\text { tentang dampak lingkungan dan budaya } \\
\text { pariwisata. }\end{array}$ \\
\hline 7. & $\begin{array}{l}\text { Bekerja sama dengan } \\
\text { yang lain untuk } \\
\text { mempertahankan } \\
\text { lingkungan } \\
\text { budaya }\end{array}$ & $\begin{array}{l}\text { - bekerja sama dengan individu dan organisasi } \\
\text { lain untuk memajukan perbaikan lingkungan } \\
\text { dan berkelanjutan } \\
\text { - mematuhi semua konvensi internasional dan } \\
\text { hukum nasional, negara bagian dan lokal untuk } \\
\text { menjaga alam lingkungan dan kepekaan budaya }\end{array}$ \\
\hline
\end{tabular}

Oleh sebab itu, dalam pengembangan destinasi pariwisata hendaknya jangan hanya dilihat sebagai alat memancing dolar turis belaka, melainkan sebagai wahana untuk memperkokoh dan mengembangkan kebudayaan setempat, sambil memperluas kesempatan kerja dan mengatasi kesejahteraan ekonomi masyarakat. 


\section{Kesimpulan}

Bila berdasarkan kasus dan analisa dari teori Faucault dalam aliran poststrukturalis, dapat disimpulkan bahwa konsep ecocracy yang diterapkan lebih cenderung weak sustainability daripada strong sustainability. Hal ini dapat diidentifikasi dari kurang memperhatikannya kesejahteraan ekonomi bagi masyarakat, adanya oknum yang masih kurang bertanggung jawab dalam menjaga keseimbangan lingkungan, serta kurangnya rasa keadilan bagi masyarakat dimana masih terbatasnya hak dalam pengelolaan sumber daya alam, akses air bersih dan terbatasnya jangkauan pendidikan. Sehingga, perlu adanya sinergi antara masyarakat, pemerintah, dan pelaku industri pariwisata harus mempunyai komitmen yang sama dalam pengembangan destinasi pariwisata yang pro terhadap lingkungan. Sehingga hak masyarakat dalam menerima jaminan lingkungan yang layak dapat dirasakan tanpa merasakan pencemaran lingkungan. Pemerintah tetap mengimplementasikan kebijakan-kebijakannya dengan program yang strategis agar dapat mewujudkan peningkatan devisa negara. Sedangkan para pelaku usaha pariwisata tetap memperhatikan keseimbangan lingkungan dan melengkapi dokumen-dokumen yang dibutuhkan dalam pengendalian lingkungan. Agar meminimalisir terjadinya kerusakan lingkungan yang berakibat fatal terhadap kehidupan ekosistem.

\section{Daftar Pustaka}

Asdhiana, Made. 2015. Pariwisata Ekologi Jadi Andalan melalui https://travel.kompas.com/read/2015/04/12/120700427/Pariwisata.Ekologi.

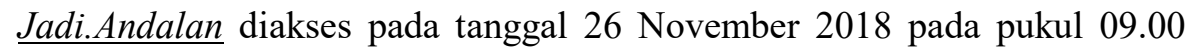
WIB

Castro, C.J. 2004. Sustainable Development: Mainstream and Critical Perspectives. London and New Delhi: Sage Publication

Charter of Fundamental Right of The European Union Pasal 37

Ditjen PDP. 2015. Rencana Strategis Pengembangan Destinasi dan Industri Pariwisata Tahun 2015-2019. Jakarta

Komisi Pembaruan Agraria (2018) Pariwisata dan Konservasi Labuan BajoKomodo vs Hak hidup Masyarakat melalui http://www.kpa.or.id/news/blog/kpa-arc-dan-ssp-pariwisata-dan- 
konservasi-labuan-bajo-komodo-menghalangi-hak-hidup-masyarakat-lokal diakses pada tanggal 26 November 2018 pada pukul $09.00 \mathrm{WIB}$

Mathew, Freya. 2005. Ecology and Democracy. London: Frank Cass

Mathews, David. 2014. Ekologi Demokrasi. Jakarta: Kettering Foundation Press

Sutisna, N. 2006. Enam Tolok Ukur Pembangunan Berkelanjutan. Jakarta: Regional Development Institute

Triana, Nita. 2014. Pendekatan Ekoregion Dalam Sistem Hukum Pengelolaan Sumber Daya Air Sungai di Era Otonomi Daerah. Purwokerto: Pandecta

Undang-Undang 1945 Pasal $28 \mathrm{H}$ ayat (1)

Undang-Undang 1945 Pasal 33 ayat (3)

Undang-Undang 1945 Pasal 33 ayat (4)

Undang-Undang Nomor 32 Tahun 2009 tentang Perlindungan dan Pengelolaan Lingkungan Hidup

Weaver, David. 2006. Sustainable Tourism, Theory and Practice. Burlington: Elsevier

Zusmelia. 2007. Mengkaji Ulang Perspektif Desentralisasi Demokrasi Sumberdaya Alam: Sebuah Langkah Menuju Cita-Cita Sustainable Development. Jurnal Sodality: Jurnal Transdisiplin Sosiologi, Komunikasi, dan Ekologi Manusia. Vol. 01(01) 